\title{
PUBLIC DEFENDERS: THE VANGUARD OF REDEMPTION A Tribute to David Bodiker
}

\author{
Jonathan A. Rapping*
}

Before I begin with the discussion, I want to share with you something I have been thinking about since this morning. Earlier today I had breakfast with some students. We were talking about careers in criminal justice and about how difficult it can be. One of the challenges that most concerned them was the meager salaries paid to public interest lawyers. One of the students explained that he has young triplets. He said he needed a job that would ensure that he could make money to support them. I want to share my response to this student with all of you law students in this room. I absolutely understand the need to pay the bills and the need to take care of our financial obligations. But you are all about to become lawyers. You will make enough money to take care of your obligations. There may be things that are not necessities that you will have to sacrifice to do work that is meaningful to you. But you will make ends meet.

But what I want to share with you is my belief that, in our concern about the financial rewards of a career, we sometimes overlook something else really important in being a parent. It is being a role model; living the values we preach. I think about this a lot because I have two young children. My children were born into Gideon's Promise, the organization my wife and I founded to build a movement of public defenders to drive reform in some of our nation's most broken justice systems. Every six months, they have the chance to be surrounded by the most amazing group of public defenders. They learn from them, they are inspired by them, and their values have literally been shaped by them. And as I always tell my students, there is nothing more important you can do with your law degree than to make sure you use it to live your values. Only then can you be a role model to the people who are important to you. You could have the nicest house and the nicest car in the world. If your children don't see you living what you preach, they won't live it either. And so, I would encourage you to spend your time in law school figuring out your purpose.

Every year, I do a session at orientation for our students at Atlanta's John Marshall Law School, and I ask them, "Why are you here?" They raise their hands

* Jonathan A. Rapping is the Founder and President of Gideon's Promise, and a Professor of Law and Director of the Honor's Program in Criminal Justice at Atlanta's John Marshall Law School. This article is an adaptation of the Bodiker Lecture delivered in 2016 at The Ohio State University Moritz College of Law. Consequently, some citations have been eschewed or moved to the beginning of the paragraph for readability. 
and one after the other, and they say things like, "I want to help a particular community," "I am interested in fighting for a particular cause," or "I want to change the world." They all have some noble reason for being there. They are idealistic. I then share with them a quote from a law student that says, "[T]he first thing I lost in law school was the reason [why] I came." "Those of you who have gone to law school understand what that means.

I tell them you're about to enter a first year where we are going to teach you law using the casebook method. You're going to learn that the law can be reduced to rules and doctrine. It can be reduced to black letters on a white page. If you are not careful, you can soon forget there are people behind the cases. If you're not careful you can lose sight of why you came to law school. You can lose sight of your passion. I would urge you all not to do that. You must find and nurture your purpose as a lawyer.

So, that now brings me to where I wanted to start. I wanted to begin by sharing my belief that public defenders are an overlooked, underappreciated, but critically important piece of a broader discussion about justice in America. We've embraced a narrative in America; a narrative about justice that puts labels on people. It drives us subconsciously to see people in certain ways. I believe as lawyers, we have the power to collectively, through telling stories, change that narrative, change that perception, and change that reality.

Dean Michaels talked about the work Gideon's Promise does to train and support public defenders. All that is part of an effort to build a movement of public defenders to start to change the way we think about justice and how poor people deserve to be treated. I want to show you a video that I saw. ${ }^{2}$ It is about a father and his daughter. The father pretends to be able to provide his little girl everything she wants. But he keeps from her the truth that he is poor; that he works any odd job he can find; that he really struggles to give her the things she wants. This video really moved me, maybe because I'm a father with a daughter who means the world to me. Maybe because I cannot imagine not being able to provide for my daughter. Maybe because I've met so many people like this man in my twenty-plus years as a lawyer.

That is a story. It is a story about a father. It is a story about a hard worker. It is a story about a man who is giving. I don't think anyone in the room, whether you're a parent or not, can help but be moved by that story. But obviously, it is also a story about a man who would do anything for his daughter, literally anything. And I suspect if he could not find that next odd job; if he had nowhere else to turn; if he had to in order to make sure his daughter was fed; he might even steal a sandwich or a loaf of bread. And when that happens, should he be arrested, he would be brought into a court system and he would be labeled a thief. There

1 William P. Quigley, Letter to a Law Student Interested in Social Justice, 1 DePAUL J. Soc. JUST. 7, 8 (2007).

2 MetLife Hong Kong, "My Dad's Story": Dream for My Child, YouTube (Jan. 27, 2015), https://www.youtube.com/watch?v=3bdm4NBYxII [https://perma.cc/4FUY-PRG6]. 
would be a prosecutor who would make a charging decision who would be too overwhelmed to get to know the actual person. He would go through that system, only known as a thief. The system wouldn't know about his love for his daughter. It wouldn't know about how hard he worked. It wouldn't know any of that unless there was someone who is there to tell his story. Someone who was there to humanize him. Without advocates to give the most marginalized among us a voice, stories are never heard and communities are stripped of their humanity.

I have to say that it is such an honor to give this lecture in the name of David Bodiker, because he spent thirteen years doing that for poor people who had no voice, giving a voice to people in Ohio who otherwise would have no one else to speak for them. There is no, more noble work. I talk about how important it is to me not just to be a fulfilled professional, but to be a role model as a father. I had the great privilege of meeting David's daughter, Amy. I met his wonderful wife, Connie. I got to meet the "Bod Squad," all of the friends who loved him. I've met so many people who have been moved by the stories that David Bodiker has told throughout his career. It is an example for all of us in the room as we think about how we can be the storytellers needed to inject humanity back into the system, because quite frankly, we have a system that has lost sight of humanity. ${ }^{3}$

As a nation, we have recently been awakened to the reality that some lives are not valued. We have been forced to reckon with this truth as we have been exposed to a seemingly endless spate of highly publicized and very violent police encounters. It started two and a half years ago in Ferguson, Missouri with the shooting death of Michael Brown. We saw Eric Garner killed in New York; twelve-year-old Tamir Rice right here in Ohio; Walter Scott in North Charleston, South Carolina; Freddy Gray in Baltimore; Samuel DuBose in Cincinnati; and Sandra Bland down in Texas. Just this summer, as we were preparing to welcome our ninth Gideon's Promise class, we learned about the deaths of Alton Sterling and Philando Castile. Most recently, Terence Crutcher and Keith Lamont Scott were shot to death by police.

These incidents awakened us to the fact that some lives in this country are deemed less valuable. But, for every person who dies during a violent police encounter, tens of thousands are arrested. They are thrown into the criminal justice system. They are processed through that system into cells. Their lives are often destroyed, sometimes literally. Just this summer, a seventy-year-old man named Lester Irby was a pretrial detainee in the D.C. jail. ${ }^{4} \mathrm{He}$ was detained on a charge of assault. The air conditioning in the jail broke down; it was like an oven inside. Lester Irby died being held pretrial for a crime he had yet to be convicted of.

3 See Jonathan A. Rapping, Reclaiming Our Rightful Place: Reviving the Hero Image of the Public Defender, 99 Iowa L. REv. 1893, 1893 (2014) (suggesting we have come to accept an embarrassingly low standard of justice for poor people accused of crimes).

4 See Mark Segraves \& Andrea Swalec, DC Inmate Dies Amid Concerns About Heat Inside, NBC 4 WASH. (July 15, 2016, 7:21 PM), http://www.nbcwashington.com/news/local/DC-Jail-InmateDies-Amid-Concerns-About-Heat-Inside-387020911.html?_osource=SocialFlowTwt_DCBrand [https://perma.cc/XLJ4-R2L2]. 
Many of you may know the story of Kalief Browder. At sixteen-years-old, Kalief Browder was accused of stealing a backpack in the Bronx. ${ }^{5}$ He was held on a bond and he spent three years at Rikers Island. For two of those years he was held in solitary confinement. He endured beatings from prison guards and fellow inmates. After three years, because of a lack of evidence, the prosecution dismissed the charges against Kalief Browder. But not before the damage to this teenager was already done. He got out and went home, but he never recovered from the deterioration of his mental health caused by his mistreatment. In 2015, his mother found him hanging from an air conditioning vent outside of his bedroom window. ${ }^{6}$

The system killed Kalief Browder. It's a system that identifies certain communities to be monitored and punished. We are unmoved by this selective policing and prosecution because we've embraced a narrative that says the people in these communities are others. ${ }^{7} \mathrm{We}$ are nonplussed as these men and women are processed through our court system. We do not even recognize the extent to which their loved ones, who come to watch the proceedings, are so often treated with no dignity. Members of these otherized communities begin to understand that they are not as valuable as other people. It is a lesson that is passed along to their children, simply from what they observe in the system.

These men and women are often sent to detention facilities that are overcrowded, where they sit either waiting for trial or serving sentences. Children, forced to visit parents through thick glass on phones, begin to learn at a very early age that some lives aren't as valuable. Should those in the system ever get out, many of them will never be able to return to their homes or jobs, they won't be able to vote, and they may be rendered homeless. Out on the streets with their children, many enter a cycle of despair. As lawyers, it's our obligation to address that.

But the narrative that strips some of their dignity is so pervasive. I was following the appointment of Loretta Lynch, now almost two years ago. Loretta Lynch would be the first African American woman to hold the position of the Attorney General for the United States Department of Justice. ${ }^{8}$ I remember

5 Jennifer Gonnerman, Before the Law: A Boy Was Accused of Taking a Backpack. The Courts Took the Next Three Years of His Life, New Yorken (Oct. 6, 2014), http://www. newyorker.com/magazine/2014/10/06/before-the-law [https://perma.cc/8NMB-89RM].

6 Jennifer Gonnerman, Kalief Browder, 1993-2015, New YorkeR (June 7, 2015), http:// www.newyorker.com/news/news-desk/kalief-browder-1993-2015 [https://perma.cc/VR8H-7D3D].

7 See Craig Haney, Politicizing Crime and Punishment: Redefining "Justice" to Fight the “War on Prisoners," 114 W. VA. L. Rev. 373, 406-07 (2012); see also Elayne RapPing, LAW AND JUSTICE AS SEEN ON TV 3 (2003) (identifying a shift in TV series about crime and justice in which the defense-attorney hero has slowly been replaced by heroic policemen and D.A.s).

8 Athena Jones, Loretta Lynch Makes History, CNN Politics (Apr. 27, 2015, 1:27 PM), http://www.cnn.com/2015/04/23/politics/loretta-lynch-attorney-general-vote/index.html [https://perma.cc/4HE6-NPTP]. 
reading an article in the New York Times when her name was being considered. ${ }^{9}$ The article discussed her hiring practices and shared a question that she used during hiring interviews. The applicant is told that $\mathrm{s} / \mathrm{he}$ is prosecuting a violent crime. The witness, an elderly woman, is unwilling to testify. Presumably she is terrified. "The case hangs in the balance. What do you do?"10 You can imagine the young prospective prosecutor struggling. The interviewee wants to balance the need to secure a conviction with the interest in treating the older woman with respect. As the reader imagines the future lawyer trying to identify the compassionate answer, Loretta Lynch provides the simple, and obviously correct, response. Loretta Lynch had a simple answer; "Nana's going to jail." 11

Now I don't mean this as a critique of Loretta Lynch. This is a critique of a system. It is a system that teaches prosecutors that the ultimate goal is securing convictions. Anyone who may frustrate that end is the enemy. If that means "Nana's going to jail"; well, the ends justify the means.

So I ask you students, how did we get here? How did we get to a point where we stood by as 2.3 million people became locked away in America? ${ }^{12}$ I want to turn to that because I think it has to do with the idea of the narrative I've been talking about. I think it has to do with a narrative about justice that we have embraced.

Consider the book Ordinary Injustice, by Amy Bach. ${ }^{13}$ Amy Bach is a lawyer and a reporter who investigated criminal justice in America. She went around the country looking at criminal justice systems and she came to the conclusion that the one thing that defines all criminal justice systems is that they have come to accept injustice. She looked at judges, she looked at prosecutors, and she looked at defense lawyers. She found that all have come to accept injustice. That injustice is actually the norm in America. It is ordinary. Ordinary injustice defines justice in America.

Amy Bach tells us that "[o]rdinary injustice results when a community of legal professionals becomes so accustomed to a pattern of lapses that they can no longer see their role in them."14 The book is not about a profession filled with bad people. It is about a system filled with lawyers, defenders, prosecutors, and judges who truly want to do justice. They believe they are doing justice. They have just lost sight of what it is.

9 Matt Apuzzo, Nominee for Attorney General Less an Activist than Holder, N.Y. TIMES (Jan. 12, 2015), https://www.nytimes.com/2015/01/13/us/politics/loretta-lynch-attorney-generalnominee.html?mcubz=1 [https://perma.cc/6Z6F-7FCH].

10 Id.

11 Id.

12 Peter Wagner \& Bernadette Rabuy, Mass Incarceration: The Whole Pie 2016, PRISON POL'y INITIATIVE (Mar. 14, 2016), https://www.prisonpolicy.org/reports/pie2016.html [https://perma. $\mathrm{cc} / 3 \mathrm{Y} 5 \mathrm{~V}-\mathrm{J} 27 \mathrm{~T}]$.

13 See generally Amy Bach, Ordinary InJustice: How America Holds Court (2009).

14 Id. at 2 . 
You may wonder how that could happen. Well, I want to show you another video that helps explain it. ${ }^{15}$ It shows a young boy, freezing on the streets of New York. It is five degrees and he only has a t-shirt and a garbage bag to keep him warm. Hundreds of people walk past this child as he curls up in the garbage bag shivering. For two hours, no one stops to help. Then one man does. A homeless man goes over to the child. He gives the boy his coat. He gives the boy his money. He hugs the child.

I show this video to public defenders I speak with across the country. I ask the audience: what they would have done? Most believe they would have stopped. I imagine most of the hundreds of people in the video would believe the same if they watched it in this room. And I don't believe these are bad people, they are human beings who have been exposed to so much misery, so much poverty, so much injustice that human nature drives them to become indifferent. We all can build a wall of indifference as a defense mechanism that allows us to walk past people in need.

My eight-year-old son asked me the other day; he said, "Daddy if you could be anyone in the world other than me, Aaliyah (his sister), or Mommy, who would you be?" I said, "I don't know Lucas, who would you be?" He says, "I would either be Antonio Brown (his favorite football player), or a homeless person." "A homeless person?" I asked. "Why would you be a homeless person?" He said, "Because then I would know what it feels like and I could grow up to do something about it."

Some of you who have heard me speak before may have heard me tell another story about my daughter. When she was a child, she would open up her piggy bank and fill a plastic baggy with change to give to the homeless man each morning who we passed on the way to her school. Well, one day we were walking down the street when a man said to me, "Sir, could you spare a dollar?" I said, "I'm sorry sir, I can't help you." As we kept walking, I felt this tug on my sleeve. I looked down and it was my daughter. She said "Daddy?" And I said, "Yeah, baby?" She said, "Daddy, doesn't that man need a dollar more than you?" I said to myself, "Yeah of course he does." Then I thought to myself, "Where did she learn that?" Where did Lucas learn that? Of course they learned it from me and from their mother. But all of us can become blind to the values we hold dearest, the values we teach our own children, if we don't guard against indifference.

Nowhere is the need to guard against indifference greater-and I'm talking specifically to you law students here at OSU-nowhere is the need greater than in the arenas that deal with poor people who have no access to justice. And nowhere will you confront pressure to abandon your values more than in those arenas.

What is it that made the one man stop to help the homeless child after hundreds of people walked past? He was homeless, so he had empathy. He had

15 MoeAndET, The Freezing Homeless Child - Little Boy Left in the Cold! (Social Experiment), YouTuBE (Feb. 23, 2015), https://www.youtube.com/watch?v=5CwCvpEMEJU [https://perma.cc/37Z5-XTVX]. 
compassion. If there is one thing that I think is most important to teach in law school, it is to teach lawyers to be empathetic. I try my best to do it with my students. But it is hard. That is not the focus of law schools; nor of the legal profession. When we say we train law students to think like lawyers, we mean we are teaching them to be logical; rational; that there is no room for feeling.

Of course, we need to ensure future lawyers come out of law school with all the skills needed for the job. But how can we also teach them to care about people? To care deeply? To commit themselves to caring? Only when we do that do we start to address some of the problems I am talking about today.

So, on the theme of narrative, I want to go back and think about how we got to this narrative where we have "otherized" certain populations of people. To do that, I want to go back in time, back to the turn of the $20^{\text {th }}$ Century. Think about what justice looked like for marginalized communities, particularly African Americans, all across the country but largely in the South where I work. ${ }^{16}$ Think about what justice looked like in the decades following Reconstruction. For some, there really was no justice. There was simply an accusation levied. A lynch mob gathered. They found the nearest tree, and an execution occurred. And over time, as a nation we started to tire of that. We started to awaken to the fact that this is completely inconsistent with who we claim to be. And the nation started to put pressure on Southern justice systems. And the systems in turn made a deal with the lynch mobs. They told them, "Look, you're making us look bad." And the Southern justice systems made an implicit bargain with lynch mobs. ${ }^{17}$ "Quit the lynching, bring them to us, and we will very quickly try them, convict them, and execute them." And so we entered an era of legal lynching. Perhaps best epitomized by the Scottsboro Boys, where nine children were pulled off a train and accused of raping two white women. ${ }^{18}$ Twelve days later, the boys were rushed to trial. They were given one lawyer who was nearly seventy-years-old and allegedly rapidly losing his ability and senses. ${ }^{19}$ Their second appointed lawyer wasn't from Alabama, had an alcohol problem, and knew nothing about Alabama law or procedure $^{20}$ Neither wanted to be the Scottsboro boys' lawyers. But they got drafted that morning, they went to trial that afternoon, and after trials that lasted less than a few hours each, eight of the nine Scottsboro boys were sentenced to die. ${ }^{21}$ Only one, a thirteen-year-old, was spared a death sentence because the State

16 See Rapping, supra note 3, at 1894.

17 See generally Michael J. Klarman, Powell v. Alabama: The Supreme Court Confronts "Legal Lynchings," in CRIMINAl Procedure StORIEs 1-2 (Carol S. Steiker ed., 2006) (discussing the rise and fall of "legal lynchings" in the South and their subsequent implications in the criminal justice system).

18 See id. at 1 (discussing the sentencing of Scottsboro Boys as an example of "legal lynchings").

19 Id. at 3.

20 See id. 3-4.

21 See id. at 5. 
did not seek it. ${ }^{22}$

And that case became a cause célèbre. All across the world, people started saying America is hypocritical. America claims to be the beacon of justice, but it's not living up to that claim. We started to cheer for advocates to make the fight fair. And I really believe that we started to enter a heyday for rights of poor people accused of crimes. We started to, at least through lip service, applaud advocates for the poor. We entered an era where public defenders were heroes. There was a TV show in 1954 called The Public Defender. ${ }^{23}$ People would come home, gather around their TV set, and watch a show about public defenders. In 1955, the next year, there was a comic book called the Public Defender. ${ }^{24}$ The cover has a picture of a public defender who is getting shot at. His hat is flying off his head and his pipe is flying out of his mouth as he dodges bullets. He's a hero, and kids wanted to be the public defender. They're coming to the newsstand thinking, "I don't care about Spider-Man or Wonder Woman; I want to be the public defender." And public defenders are heroes. Public defenders in the room, you are heroes.

In Hollywood, the nation's biggest stars played criminal defense lawyers. Jimmy Stewart starred in Anatomy of a Murder as a defense lawyer-hero. ${ }^{25}$ It was 1959, and we loved Stewart as a defense lawyer representing another man charged with murder. Then three years later, in 1962, To Kill a Mockingbird hits the silver screen. ${ }^{26}$ Atticus Finch, perhaps the quintessential public defender, embodies what justice in America means. A small-town lawyer in Alabama appointed to represent a black man accused of raping a white woman. He fights for justice despite the derision he receives from the community. And we love Atticus Finch.

And I think it is important to recognize that to understand the Court's decision in Gideon, you have to appreciate the context of the times. ${ }^{27}$ Because, in 1963, when Gideon was decided, as a nation we were struggling to live up to the promise of justice in so many walks of life. We were mobilizing to fight for equal justice around voting rights, access to housing, equal education opportunities, and fair commerce practices. And along with those areas, we were concerned about inequities in the criminal justice system. In this sense, Gideon was a civil rights case. It belongs alongside the long menu of cases and legislation that contributed to advancing civil rights in America.

22 See id.

23 See The Public Defender (CBS television broadcast Mar. 11, 1954-June 23, 1955); see also The Public Defender, IMDB, http://www.imdb.com/title/tt0046638/ [https://perma.cc/G5AN7V4Z] (last visited Oct. 2, 2017).

24 See Public Defender in Action, Comic BooK Plus, http://comicbookplus.com/?cid=1215 [https://perma.cc/W2ZK-KN6K] (last visited Oct. 2, 2017).

25 See Anatomy of a Murder (Carlyle Prods. 1959); see also Anatomy of a Murder, IMDB, http://www.imdb.com/title/tt0052561/ [https://perma.cc/P23G-G3P4] (last visited Oct. 2, 2017).

26 See To Kill a Mockingbird (Universal Int'1 Pictures et al. 1962); see also To Kill a Mockingbird, IMDB, http://www.imdb.com/title/tt0056592/ [https://perma.cc/PSL4-3L6N] (last visited Oct. 2, 2017).

27 Gideon v. Wainwright, 372 U.S. 335 (1963). 
It is against this backdrop that the right to counsel, the guarantee of a public defender, was born. The public defender was birthed as a civil rights hero.

In popular culture, criminal defense lawyers were idolized. Perry Mason was the longest running lawyer show of its time. ${ }^{28}$ We also rooted for the outlaws. As a kid, all my favorite movies were about outlaws. Not only did we love the public defenders, we loved the outlaws. We loved the individuals who were outside the law. We loved Paul Newman as Cool Hand Luke, a man who went to prison for cutting the tops off parking meters. ${ }^{29}$ We loved Warren Beatty and Faye Dunaway as Bonnie and Clyde, two bank robbers. ${ }^{30}$ We loved Butch Cassidy and Sundance Kid, two train robbers. ${ }^{31}$ And we loved Al Pacino in Dog Day Afternoon, as he played a sympathetic bank robber. ${ }^{32}$ We loved them because we saw them as human beings, flawed but very lovable human beings. It said something about our values. We had not yet come to terms with the intersection of race and crime. This narrative was told with all of the players having white faces. But through these stories, we cheered for the idea of justice that protected the individual against the power of a cold, uncaring state.

And then, we were forced to confront race as the Civil Rights Movement consumed our national consciousness. African Americans were taking to the streets demanding basic civil rights. And Southern politicians, like George Wallace, saw this activism as an opportunity to galvanize white working-class voters. $^{33}$ These politicians started to brand the protesters as menaces; as outsiders. This was the start of a decades-long tough on crime narrative. ${ }^{34}$

In the 1970s, Richard Nixon launched the War on Drugs. But it wasn't a war on all drugs. ${ }^{35}$ It was a war on drugs predominantly used in inner cities. ${ }^{36}$ In the

28 See J. Dennis Bounds, Perry Mason, EnCyClopedia of Television, (2017); see also Perry Mason, IMBD, http://www.imdb.com/title/tt0050051 [https://perma.cc/LDA6-P2Q3] (last visited Oct. 2, 2017).

29 See Cool Hand LuKe (Jalem Prods. 1967); see also Cool Hand Luke, IMDB, http://www. imdb.com/title/tt0061512/ [https://perma.cc/HL7T-KHY4] (last visited Oct. 2, 2017).

30 See Bonnie And Clyde (Warner Bros./Seven Arts \& Tatira-Hiller Prods. 1967); see also Bonnie and Clyde, IMDB, http://www.imdb.com/title/tt0061418/ [https://perma.cc/527W-9MRM] (last visited Oct. 2, 2017).

31 See Butch Cassidy and the Sundance Kid (Twentieth Century Fox Film Corp. et al. 1969); see also Butch Cassidy and the Sundance Kid, IMDB, http://www.imdb.com/title/tt0064115/ [https://perma.cc/W38E-48UT] (last visited Oct. 2, 2017).

32 See Dog Day Afternoon (Warner Bros. et al. 1975); see also Dog Day Afternoon, IMDB, http://www.imdb.com/title/tt0072890/ [https://perma.cc/JZV9-DN2J] (last visited Oct. 2, 2017).

33 See Rapping, supra note 3, at 1897.

34 See Richard Nixon, Remarks About an Intensified Program for Drug Abuse Prevention and Control 37 PUB. PAPERS 202 (June 17, 1971), http://www.presidency.ucsb.edu/ws/?pid=3047 [https:// perma.cc/JH5Q-88W9].

35 See id.

36 See Michelle Alexander, The New Jim Crow: Mass Incarceration in the Age of COLORBLINDNESS 51-58 (rev. ed. 2012) (provides a comprehensive discussion of the War of Drugs and how it has influenced criminal justice in America). 
1980s, Ronald Reagan ratcheted up the War on Drugs as crack cocaine burst on the scene. ${ }^{37}$ We started to experience more draconian policies, including mandatory minimum sentences. ${ }^{38}$ The tough on crime mindset that swept the nation is probably best epitomized by the Willie Horton campaign that George H.W. Bush used to sink the presidential hopes of Michael Dukakis. ${ }^{39}$ Michael Dukakis, as the governor of Massachusetts, oversaw a furlough program. Unfortunately, Willie Horton was given a weekend long furlough and did not return. ${ }^{40}$ He later committed some terrible violent crimes, and Willie Horton became the face of George Bush's campaign against Michael Dukakis. ${ }^{41}$

The media joined in on the dehumanizing of black and brown men accused of crimes. This is perhaps best illustrated in the case of the Central Park jogger, a young woman who was brutally raped and beaten in Central Park while out for a run. ${ }^{42}$ Authorities immediately accused five young black and Latino teenagers, and the media automatically dubbed them a "wolf pack." ${ }^{43}$ The media also coined the phrase "wilding." 44 The language was explicitly designed to promote the image of animals searching for prey. It turns out these five young men were innocent. The story is told brilliantly by Ken Burns in the documentary, The Central Park Five. ${ }^{45}$ But the truth did not matter in a world that was driven by a tough on crime narrative. Criminality was assumed for certain communities.

And the strategy to win votes by adopting a tough on crime posture would soon be embraced by Democrats as well as Republicans. In 1991, Bill Clinton was campaigning to become President of the United States. He was the governor of Arkansas at the time, and he had a problem back home. There was a man on death row named Ricky Ray Rector. ${ }^{46}$ After killing a man, Ricky Ray Rector also killed

37 See id.

38 See id.

39 See Jonathan A. Rapping, National Crisis, National Neglect: Realizing Justice Through Transformative Change, 13 U. PA. J.L. \& Soc. CHANGE 331, 341 n.74 (2010).

40 See id.

41 See id.

42 Craig Wolff, Youths Rape and Beat Central Park Jogger, N.Y. Times (Apr. 21, 1989), http://www.nytimes.com/1989/04/21/nyregion/youths-rape-and-beat-central-park-jogger.html [https://perma.cc/N98L-QGKX].

43 Benjamin Weiser, 5 Exonerated in Central Park Jogger Case Agree to Settle Suit for $\$ 40$ Million, N.Y. TIMES (June 19, 2014), https:/www.nytimes.com/2014/06/20/nyregion/5-exoneratedin-central-park-jogger-case-are-to-settle-suit-for-40-million.html [https://perma.cc/CV8K-TSA6].

44 Id.

45 The Central Park Five: About the Film, PBS, http://www.pbs.org/kenburns/centralpark five/about/overview/ [https://perma.cc/5X8Z-ET25] (last visited Oct. 2, 2017); see also THE CENTRAL PARK FIVE (Florentine Films \& WETA 2012).

46 Peter Applebome, THE 1992 CAMPAIGN: Death Penalty; Arkansas Execution Raises Questions on Governor's Politics, N.Y. TIMES (Jan. 25, 1992), http://www.nytimes.com/ 1992/01/25/us/1992-campaign-death-penalty-arkansas-execution-raises-questions-governor-s.html [https://perma.cc/Y74U-7MTU]. 
a police officer who tried to arrest him, before putting a gun to his head and trying to take his own life. ${ }^{47} \mathrm{He}$ didn't take his own life, but he did blow away a portion of his brain. This injury rendered him terribly mentally limited. He was a completely different person. Rector was left with no real connection to reality. ${ }^{48}$ He was sentenced to die and had an execution date set during the primary season.

As Bill Clinton was campaigning to be president, he had a decision to make: should he commute the sentence of Ricky Ray Rector? I recall reading an article in the New Yorker that discussed how Bill Clinton was agonizing over this decision. ${ }^{49} \mathrm{He}$ knew it wasn't right to execute a man who was so limited. But he also understood that if he commuted Rector's sentence it would be the end of his campaign. ${ }^{50} \mathrm{He}$ flew back to Arkansas to preside over that execution. ${ }^{51}$

The night before Ricky Ray Rector was executed he ordered his last meal. For dessert, he asked for a piece of pecan pie. ${ }^{52} \mathrm{He}$ was full after his meal, so he asked that the pecan pie be put aside for later. Ricky Ray Rector was so limited he didn't realize there would not be a later. ${ }^{53}$ But Clinton understood that if he wanted to be president he could not afford to show Rector any mercy.

In 1995, Princeton Professor John Dilulio coined the phrase "super-predators" to describe young, violent criminals. ${ }^{54}$ It became a catch phrase used to invoke fear and garner support for tough-on-crime policies. As first lady, Hillary Clinton, now famously, made a speech rallying support for her husband's criminal justice policies by declaring the need to bring these "super-predators . . . to heel." "55 And I don't mean to pick on Hillary Clinton exclusively. Everyone jumped on board with that phrasing. Once the "super-predator" was born, instead of outlaws in the media being portrayed by the likes of Paul Newman and Jessica Lange, they all started to look like young callous toughs like those in Menace II Society, ${ }^{56}$ and Juice. ${ }^{57}$ If not explicit, the connection between race and dangerousness was

47 Id.

48 Id.

49 Marshall Frady, Death in Arkansas, New Yorker, Feb. 22, 1993, at 105.

50 Id.

51 Id.

52 Id. at 128.

53 Id.

54 Steve Drizin, The 'Superpredator' Scare Revisited, HufFINGTON Post: THE BLOG (June 9, 2014), http://www.huffingtonpost.com/steve-drizin/the-superpredator-scare_b_5113793.html [https:// perma.cc/8KK7-B7V7].

55 Watch Hillary Clinton's Controversial 1996 'Super-Predators' Comment, WASH. POST (Feb. 26, 2016), https://www.washingtonpost.com/video/politics/watch-hilary-clintons-controversial1996-super-predators-comment/2016/02/26/1d0dcce4-dc88-11e5-8210-f0bd8de915f6_video.html [https://perma.cc/RQ3Y-Q6RS].

56 See Menace II Society (New Line Cinema 1993); see also Menace II Society, IMDB, http://www.imdb.com/title/tt0107554/ [https://perma.cc/4ERW-4KZH] (last visited Oct. 2, 2017).

57 See JUICE (Island World 1992); see also Juice, IMDB, http:/www.imdb.com/title/ tt0104573/ [https://perma.cc/B7YJ-H4PZ] (last visited Oct. 2, 2017). 
always at least implicit.

Even judges who ran for election were targeted for being too soft on crime. In a 2010 attack ad against Illinois Supreme Court Justice Thomas Kilbride, listeners hear an actor portraying convicted murderer Paul Runge say: "I was convicted of sexual assault on a mom and her ten-year-old daughter . . . then I slashed their throats ... Unfortunately for felons like us, other justices overruled Kilbride and our appeals were denied." 58 A narrator tells the audience, "Kilbride chose criminals' rights over and over again." 59

What message does that send to a judge who has to run for election? It clearly warns them not to risk finding that someone's Fourth, Fifth, Sixth Amendment rights were violated - especially if the person is accused of a violent crime - because this will be your opponent's campaign ad.

The image of the lawyer took a hit as well. No longer were public defenders portrayed by actors like Gregory Peck, as Atticus Finch. They were now cast in the image of the stuttering, incompetent, Alabama court appointed lawyer in $M y$ Cousin Vinny. ${ }^{60}$

And as far as television goes, I recall an episode of NYPD Blue, where Detective Kelly — the seasoned cop-was interrogating a guy. ${ }^{61}$ Kelly threatened the suspect until he confessed. Afterwards, a young, not so savvy detective asked Kelly if he could beat a confession out of the suspect. Kelly responded, "I believe in the Constitution and I hold on to that as long as I can. But in the case of a murderer like this who's gonna walk, I leave my gun and my jewelry outside with the Constitution." ${ }^{\prime 2}$ You can imagine the viewing audience cheering: "Yeah, leave the Constitution outside." Everyone thinks Kelly is a hero.

And what about Law \& Order, literally is the longest running crime-drama series in history, with the beginning narrative that says: "[i]n the criminal justice system, the people are represented by two separate yet equally important groups: the police who investigate crime; and the district attorneys, who prosecute the offenders. These are their stories. [Dun dun]"63

Where are the public defenders? They are literally irrelevant to the modern criminal justice narrative. We don't need defense counsel because we can arrest, prosecute, and give long sentences just fine without them. That's not what our

58 JUSTPAC, Kilbride Sides with Criminals, YouTuBE (Nov. 4, 2010), https://www.youtube. com/watch?v=10307JqaOEs [https://perma.cc/3TDC-RD69].

59 Id.

60 See My Cousin Vinny (Palo Vista Production et al. 1992); see also My Cousin Vinny, IMDB, http://www.imdb.com/title/tt0104952/ [https://perma.cc/H6RN-F9FE] (last visited Oct. 2, 2017).

61 NYPD Blue: A Tempest in a C-Cup (ABC television broadcast Nov. 16, 1993).

62 Id.; see Susan Bandes \& Jack Beermann, Lawyering Up, 2 Green BAG 2D 5, 7-8 (1998).

63 See Law \& Order (NBC television broadcast Sept. 13, 1990-May 24, 2010); see also Law \& Order, IMDB, http://www.imdb.com/title/tt0098844/ [https://perma.cc/3KEH-UY9N] (last visited Oct. 2, 2017). 
founding fathers envisioned.

Thomas Jefferson famously said, "A single zealot may commence prosecutor and better men be his victims." ${ }^{64}$ I was so honored that this award included this wonderful quote from John Adams. John Adams volunteered to defend the British soldiers accused in relation to the Boston Massacre. You have to remember, at that time, the colonists despised the British soldiers. Those British soldiers were equivalent to terrorists today. John Adams hadn't yet become vice president. He put his entire political career in jeopardy to undertake this representation. ${ }^{65}$ Afterwards, Adams said it was one of the best pieces of service he ever rendered his country. What a far cry from that narrative today.

In contrast, when John Kerry ran for president, he boasted, "I'm a veteran, I fought in a war. I've been a prosecutor. I've sent people to jail for the rest of their life." ${ }^{66}$ His bona fides lie in his history of taking people's liberty.

On the other hand, when a former criminal defense lawyer runs for office, he is more likely to be attacked. In 2014, state senator and criminal defense attorney Vincent Sheheen ran against Nikki Haley in the state gubernatorial race. An attack ad by the Republican Governor's Association tells voters: "[Sheheen] got a sex offender out of jail time, defended a child abuser, and represented others charged with violent acts." ${ }^{67}$ It goes on to say, "Sheheen defended violent criminals, who abused women and went to work setting them free." $" 68$

So, to the public defenders in the room, you are doing noble work. I hope you don't run for office. Not because you won't get elected, although your service to our democracy might stand in your way under the perverse narrative we have embraced, but because we need you right where you are.

When I was a young public defender, the trial chief in our office had a button that read, "Don't tell my mother I'm a public defender; she thinks I play piano in a whorehouse."

So, like anyone who is interested in criminal justice, I've been following the conversation around reform the last couple of years, ecstatic that criminal justice is finally on the national radar. Finally, we are talking about criminal justice reform, and it is a bipartisan conversation. You've got progressives, you've got conservatives, and you've got libertarians all agreeing that we have to fix this

64 Thomas Jefferson Quotes, AZ QUOTES, www.azquotes.com/quote/1148769 [https://perma. cc/5LV7-TEF3] (last visited Oct. 2, 2017).

65 Barry J. Pollack, Don't Attack Lawyers Who Defend Criminals: Column, USA TODAY (Oct. 12, 2016, 3:16 AM), http://www.usatoday.com/story/opinion/2016/10/12/hillary-clinton-tim-kainecriminal-defense-lawyers-attacks-column/91905114/ [https://perma.cc/9JBY-6588].

66 David Espo, Demos Voice Eagerness to Battle Bush, Deseret News (Jan. 23, 2004, 12:00AM), http://www.deseretnews.com/article/590038049/Demos-voice-eagerness-to-battle-Bush. html?pg=all [https://perma.cc/XT45-K4JG].

67 Republican Governors Association, RGA South Carolina Ad: Vincent Sheheen Protects Criminals, Not South Carolina, YouTuBE (Apr. 21, 2014), https://www.youtube.com/watch?v=nf0KN5Ijkk [https://perma.cc/KZ4Z-875C].

68 Id. 
broken system. But as you listen to the conversation and you listen to the suggested fixes, there is a critical piece missing from the discussion. What do you think it is? Public defenders! This is the reality we live in. And I know really good people who have been shaped by this system that don't get why public defenders matter so much.

One organization that I admire greatly, the Brennan Center for Justice, put out an informative collection of essays called Solutions: American Leaders Speak Out on Criminal Justice. ${ }^{69}$ They invited politicians of all stripes: Hilary Clinton, Rand Paul, and Chris Christie. ${ }^{70}$ All sorts of experts wrote essays about what we need to do to reform criminal justice in America. ${ }^{71}$ There were twenty-two chapters in total, 164 pages. The words "public defender" were mentioned once. ${ }^{72}$ "I served these communities as a public defender and for thirty-six years as Delaware's senator." 73 That was in Joe Biden's piece on community policing, literally the only mention of public defenders in twenty-two chapters about criminal justice reform. ${ }^{74}$ A throwaway line that had nothing to do with reform.

These are the men and women who speak for $80 \%$ of the people in the system and they are forgotten. During the recent presidential campaign, Hillary Clinton put together a great website on criminal justice, ${ }^{75}$ as did Bernie Sanders. ${ }^{76}$ Neither of them mentioned public defenders. Barack Obama hosted a panel at the White House to talk about criminal justice reform. He invited a prosecutor from Colorado and a police chief from Los Angeles, but no public defender was invited to the stage. ${ }^{77}$ In fact, the words "public defenders" were never uttered during that conversation. In one of his final acts as president, Barack Obama wrote a comprehensive law review article about what we need to do to reform criminal justice. ${ }^{78}$ Sixty-four pages; never mentioned public defenders. ${ }^{79}$

69 See generally Joseph Biden, JR. ET AL., SOlutions: American LeAders Speak OUt on CRIMINAL Justice (Inimai Chettiar et al. eds., 2d ed., 2015).

70 See generally id.

71 See generally id.

72 See generally id.

73 Id. at 4.

74 See generallyid.

75 See Criminal Justice Reform, HiLlaRY FOR AMERICA, https://www.hillaryclinton.com /issues/criminal-justice-reform/ [https://perma.cc/NFZ3-9JQB]_last visited Oct. 2, 2017).

76 See Issues: Racial Justice, FrIENDS OF BERNIE SANDERS, https://berniesanders.com /issues/racial-justice/ [https://perma.cc/YY83-TJQE] (last visited Oct. 2, 2017).

77 The Marshall Project Hosts Panel on Criminal Justice Reform with President Obama, THE Marshall Project (Oct. 22, 2015, 6:30 PM), https://www.themarshallproject.org/2015/10/22/ watch-president-obama-and-the-marshall-project-in-a-conversation-today-about-criminal-justice\#. OFRLzBDKt [https://perma.cc/CB76-USWR].

78 Barack Obama, The President's Role in Advancing Criminal Justice Reform, 130 HARV. L. REv. 811 (2017).

79 Id. President Obama did dedicate a single footnote to "indigent defense." See id. at 845 n. 185 . 
We are really missing the mark with this conversation about criminal justice reform. We look to policy fixes which will only tweak things here and there. We hope that by engaging in sentencing reform we can reduce the number of people locked up. We hope that by decriminalizing minor behavior we can slow down the flow of people into the system. But the problem with this approach is that, while we may succeed in reducing the number of people in prison, if we don't change the narrative, they will still be almost exclusively poor, ${ }^{80}$ and disproportionately of color. ${ }^{81}$ Maybe they will spend less time in prison, but they will instead trade a jail cell for supervision under parole or probation. The system will still be reserved for those we see as "others."

If we don't change the fact that we see poor people as others, we will not have real criminal justice reform. ${ }^{82}$ There's a leadership model called "adaptive leadership." ${ }^{\circ 3}$ It warns that the single biggest failure of leadership is to treat adaptive challenges like technical problems. A technical problem might be mending a broken bone. If I broke my arm, I need a doctor that has the technical expertise to set the bone. But let's say I have high blood pressure. I need to change my diet; I need to exercise. That's an adaptive challenge. I have to change the way I behave. You can't treat that with a technical fix.

Michelle Alexander, a former Ohio State professor, wrote an insightful book called The New Jim Crow. ${ }^{84}$ This year, a documentary came out called 13th, by Ava DuVernay. ${ }^{85}$ There's a theme in both of those works that we have always maintained systems to control African Americans. The system may have changed, but the goal has always been to marginalize those we see as "others." We traded slavery for an era of black codes and convict leasing, where a person could be arrested and used as cheap or free labor. We then went to a system of Jim Crow, and then to the current system of mass incarceration. What this thesis teaches is that you can make structural changes, but if you don't change the values that guide us as a nation, we'll replace one structure with another structure that still discriminates against the population we see as "others." And so, structural changes that make an unjust system less cruel are not enough. We must transform the values that we embrace so they are truly consistent with what justice demands.

One question I frequently get from law students who want to be in the

80 See Jonathan A. Rapping, Implicitly Unjust: How Defenders Can Affect Systemic Racist Assumptions, 16 N.Y.U. J. LegIS. \& PUB. PoL'y 999, 1018 (2013).

81 See id. at 1004.

82 See Jonathan A. Rapping, The Power to Transform Is Stronger than the Power to Punish: Public Defenders are the Key to Equal Justice, 6 L.A. PUB. InT. L.J. 72,77 (2016).

83 See Ronald Heifetz, Alexander Grashow, \& Marty Linsky, The Practice of Adaptive Leadership: ToOls and Tactics For Changing Your Organization and the World 71 (2009).

84 ALEXANDER, supra note 36.

85 13TH (Kandoo Films 2016); see also 13th, IMDB, http://www.imdb.com/title/tt5895028/ [https://perma.cc/KT86-5QBS] (last visited Oct. 2, 2017). 
criminal justice arena is whether they can have a greater impact as a prosecutor or a public defender. "I'm trying to figure out what to do. Should I be a prosecutor or should I be a defender?" They believe that as a prosecutor they hold all the power, and that as a public defender, they will just be overwhelmed. Everywhere they look the message that the prosecutor is the most powerful actor in the system is reinforced.

The Atlantic, which is a progressive think tank, did a whole conversation about race and justice in America back in 2015. ${ }^{86}$ There was one panel on the role of the court. They invited a young prosecutor from Boston, a former federal judge, and the Manhattan district attorney to serve on the panel and talk about the role of the court. No public defenders were invited ${ }^{87}$ They were discussed. At one point the young prosecutor said that he was in a defense clinic and came to believe in his three months in a defense clinic that the defense counsel had no power. $\mathrm{He}$ believed prosecutors had all the power, and that's why he became a prosecutor. The federal judge said, "You can give public defenders gigantic resources and it will make no material difference." $" 88$ And I am sure these panelists have a lot of respect for public defenders. They think the work is important, but their comments reflect a common mindset that public defenders can't make a difference.

I couldn't disagree more. As Michelle Alexander and Ava DuVernay point out, we have always had systems designed to control those we deem as "others." There have always been those who are responsible for making sure the system operates as designed. When slavery was legal, the system depended on overseers to ensure slaves did not get out of line. Convict leasing relied on prison guards to make sure that system functioned. ${ }^{89}$ During the Jim Crow era, police departments, like those in Birmingham with attack dogs and fire hoses, maintained control. Do we prefer overseers, prison guards, and police officers who are less cruel? Absolutely!

For those of you who want to be prosecutors, I urge you to enter the system and be less cruel. We need prosecutors that refuse to use bail to hold poor people because they are poor, to overcharge in order to gain leverage to coerce a plea, to respect the constitutional rights of the accused and not try to suppress potential violations that come up. We need prosecutors who can help make the system less cruel. But they cannot transform the system. By definition, they are part of the system. They maintain the system. They can influence the extent to which it treats people with dignity, but they can't transform it. ${ }^{90}$

To transform the system, we must give a voice to the people impacted by it.

86 AtlanticLIVE, The Role of the Court / Race and Justice in America, YouTuBE (Nov. 12, 2015), https://www.youtube.com/watch?v=vSmfTOXM_f8\&index=6\&list=PLwj46yNDLyTXpuPUliI36xJ4YKvu6n Rg6 [https://perma.cc/X6GX-KG82].

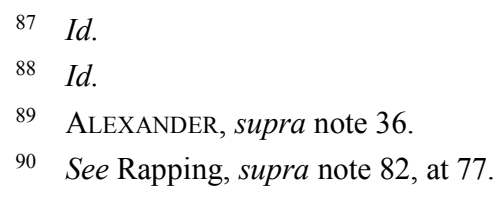


They are part of a segment of society who are told every day that their stories don't matter; that their voices don't count; that their lives are worthless.

Consider the testimony of nine-year-old Zianna Oliphant before the Charlotte City Council in the wake of the killing of Keith Lamont Scott.

I'm here today to talk about how I feel. I feel like that we are treated differently than other people and I don't like how we're treated just because of our color. We are black people and we shouldn't have to feel like this. We shouldn't have to protest because y'all are treating us wrong. We do this because we need to and we have rights. I've been born and raised in Charlotte and I never felt this way until now. I can't stand how we're treated. It's a shame that our fathers and mothers are killed and we can't see them anymore. It's a shame that we have to go to their graveyard and bury them . . that we have tears and we shouldn't have tears. We need our fathers and mothers to be by our side. ${ }^{91}$

This is such a heartbreaking video to me because I'm a father. I've got an eight-year-old and a twelve-year-old and I just can't imagine having a child who understands at the tender age of nine that their life is not valuable. She learned that because of how she sees those she loves treated every day.

In 1968, sanitation workers in Memphis took the streets with a basic message: "I am a man," literally saying, "I'm a human being, see me as a human being." 92 We like to think we're beyond that. But protesters today simply saying, "Black Lives Matter," aren't they saying the same thing? Isn't Zianna Oliphant saying the same thing? "Please notice the humanity."

And so, absolutely we need good judges, we need good prosecutors, we need good police. We need people to make the system less cruel. But to transform the system we need advocates to make sure those who have been otherized have voices that are heard.

There is an African proverb that says, "[u]ntil the lion learns how to write, every story will glorify the hunter." ${ }^{93}$ Some people in our history have always been preyed upon. They haven't had a voice, their story hasn't been told, and so instead, their story is defined by others in the prevailing criminal justice narrative.

I love public defenders. These are men and women who have given their lives to this cause like David Bodiker. We can talk about all the reforms in the world, but, if we do not ensure there are public defenders to make sure that some

91 Rohan Smith, Zianna Oliphant, 9, Breaks Down During Powerful Plea for Change in Charlotte, News.Com.Au (Sept. 28, 2016, 12:24 PM), http://www.news.com.au/world/northamerica/zianna-oliphant-9-breaks-down-during-powerful-plea-for-change-in-charlotte/newsstory/4ff690fc0d457dd91c4cdc85b0527c5c [https://perma.cc/BR4J-94WC].

92 Sanitation Workers Remember King's Last Stand, NPR (Apr. 4, 2008, 12:00 AM), http://www.npr.org/templates/story/story.php?storyId=89361277 [https://perma.cc/A7HC-T5ES].

93 Rapping, supra note 82 , at 88. 
people aren't cheating, cheating will happen. If there aren't public defenders to remind judges and prosecutors who want to do right of the humanity of people who they judge, we won't have justice. But most importantly, I believe that, with an army of public defenders, collectively we can start to change the way we think about poor people and who they are.

We can take the story of the thief and make it the story of the father, who loves one thing in the world more than anything else and that's his little baby girl. Who has worked every odd job he could find to make things right and who, through no fault of his own, had nowhere else to turn but to steal a sandwich. When that narrative changes, we'll be ready to talk about real equal justice.

I'm going to end with this. There are people desperately reaching out for help all over America. And I believe there are three kinds of lawyers in this world. There are those who have decided to go into law firms and before they know it they're making a lot of money. They're living in high rise buildings, they drive to work, and they park underground. It becomes easy to forget that these hands exist. And so they go on blissfully ignorant of the real injustice in the world.

There's a second group, and those are folks who have come to embrace a narrative that says these hands belong to demons. And they make it their mission to make sure these hands are kept away from us.

And then there's a smaller group. A group that David Bodiker represents. A group that you public defenders belong to. That's a group that says, "When I see that hand, I'm going to reach out. I'm going to grab it. I'm going to hold it. I'm going to try to help it. I might not succeed, but I know that there's value in that person knowing someone held their hand when they were at their toughest time in life." If you do that as a lawyer, you've done more than most lawyers will do in a career. To the public defenders in the room, you do that every day. Thank you!

But more than that, collectively you will hold these hands and remind us as a society that these are people; that we must treat them as people. And if we are in a courtroom as a judge, as a prosecutor, or as a defender, and we see someone being treated in a way that we would not tolerate for our own children, for our own loved ones, we will not participate. Only then will we have equal justice.

I am so honored to give the David Bodiker lecture. I'm so honored to be invited to this wonderful law school. And I'm so honored to be in a room with all of you and just share this special day. Thank you so much. 